\section{From HHMI: Doubling Down on Diversity}

\section{David J. Asai* and Cynthia Bauerle ${ }^{\dagger}$}

Undergraduate and Graduate Science Education Programs, Howard Hughes Medical Institute, Chevy Chase, MD 20815-6789

\begin{abstract}
In spite of modest gains in the past four decades, the United States has not been able to substantially improve on the pervasive underrepresentation of minorities in postsecondary science, technology, engineering, and mathematics (STEM) pathways. We suggest a way to guide a national effort to double the persistence of underrepresented minorities in STEM in the next decade.
\end{abstract}

double down: to become more tenacious, zealous, or resolute in a position or undertaking.

\section{Merriam-Webster online dictionary}

We choose to go to the moon. We choose to go to the moon in this decade and do the other things, not because they are easy, but because they are hard, because that goal will serve to organize and measure the best of our energies and skills, because that challenge is one that we are willing to accept, one we are unwilling to postpone, and one which we intend to win.

John F. Kennedy, September 12, 1962

And race matters for reasons that really are only skin deep, that cannot be discussed any other way, and that cannot be wished away.... Race matters because of the slights, the snickers, the silent judgments that reinforce that most crippling of thoughts: "I do not belong here."

Sonia Sotomayor, dissenting, April 22, 2014, Schuette v. Coalition to Defend Affirmative Action, Integration and Immigrant Rights and Fight for Equality by Any Means Necessary (BAMN), U.S. Supreme Court

Do. Or do not. There is no try.

Yoda, Star Wars Episode V, 1980

\section{SCIENTIFIC EXCELLENCE IS INCLUSIVE}

At its best, science is about identifying and then solving difficult problems. Success is measured by the extent to which the community of scientists can successfully tackle hard problems. As the diversity of the group of problem solvers increases, so too does the group's ability to find innovative solutions to difficult and complex problems (Page, 2007; Jackson and Joshi, 2011; Kets and Sandroni, 2015). As it was a half century ago when the nascent space program benefited by the inclusion of physicists and engineers who were refugees from World War II Europe, so it is today. The U.S. scientific enterprise will be at its best when its leaders are drawn from our nation's entire talent pool, a truly representative science. This is inclusive excellence in science, technology, engineering, and mathematics (STEM).
CBE Life Sci Educ September 1, 2016 15:fe6 DOI: 10.1187/cbe.16-01-0018

tPresent address: College of Science and Mathematics, James Madison University, Harrisonburg, VA 22807.

*Address correspondence to: David J. Asai (asaid (ahhmi.org).

(C) 2016 D. J. Asai and C. Bauerle. CBE-Life Sciences Education @ 2016 The American Society for Cell Biology. This article is distributed by The American Society for Cell Biology under license from the author(s). It is available to the public under an Attribution-Noncommercial-Share Alike 3.0 Unported Creative Commons License (http:// creativecommons.org/licenses/by-nc-sa/3.0).

"ASCB $®$ " and "The American Society for Cell Biology $\circledR^{\prime \prime}$ are registered trademarks of The American Society for Cell Biology. 
Since 1960, the proportion of the U.S. population that is ethnic minorities has nearly tripled (U.S. Census Bureau). Today, $37 \%$ of our population is persons of color (National Center for Science and Engineering Statistics [NCSES], 2015), and the Census Bureau projects that our nation will be "majority minority" in $\sim 25$ years. Already, more than half of the 50 million students in K-12 public schools are ethnic minorities (National Center for Education Statistics, 2013). This diversity is the legacy of our history as an immigrant nation whose origins are in large part founded on colonization, indentured servitude, slavery, and genocide of persons of color. Even as today's diversity is a product of our troubled past, it is also our greatest strength for the future.

To continue our global leadership in STEM innovation, we must find ways to replace exclusion with inclusion, drawing from the many experiences and communities that together form our country's deep and dynamic talent pool. Our great opportunity is to capture the energy and perspectives presented by our nation's ethnic diversity.

\section{WE CONTINUE TO FALL SHORT IN CAPTURING THE TALENT POOL}

Despite the general acknowledgment of the importance of diversity in science, and despite many programs and the investment of many resources, we have not been able to substantially improve the pervasive underrepresentation of minorities in STEM pathways. While the number of underrepresented minorities entering college interested in studying STEM (today, 33\%) has kept pace with the national demographics, the fraction of underrepresented minority STEM baccalaureates and STEM PhDs has remained stubbornly stuck at around 16 and 9\%, respectively. ${ }^{1}$ This disparity is not simply due to poor preparation. When the outcomes of students with similar precollege backgrounds-high school math, high school science labs, and family interest in higher education-are compared, underrepresented minorities switch out of STEM disciplines at significantly higher rates than whites and Asians (Huang et al., 2000).

\section{IT IS TIME TO DOUBLE DOWN}

Among undergraduates who enter college planning to study STEM, only $20 \%$ of underrepresented minorities complete a STEM baccalaureate degree compared with $\sim 40 \%$ of whites and Asians (Committee on Underrepresented Groups and Expansion of the Science and Engineering Workforce Pipeline, 2011). The persistence rate of minorities is halved again at the graduate level: among those with science baccalaureates, the "yield" (science baccalaureates who go on to earn a science $\mathrm{PhD}$ ) of underrepresented minorities is about half that of whites and Asians (NCSES, 2015).

What, then, would it take to double the persistence of underrepresented minorities in science? We offer three suggestions to guide a concerted national strategy.

\footnotetext{
${ }^{1}$ Baccalaureate and $\mathrm{PhD}$ degrees among U.S. citizens and permanent residents in biological sciences, computer sciences, earth and atmospheric sciences, mathematics and statistics, physical sciences, and engineering in 2012. Underrepresented minorities: black, Hispanic or Latino, and American Indian or Alaska Native (NCSES, 2015).
}

\section{Adaptation and Adoption}

Many decades of effort and experience have brought us to the point where we can describe strategies that work to dismantle institutional barriers to inclusion. The University of Maryland Baltimore Campus (UMBC) Meyerhoff Scholars Program, the University of California-Berkeley Biology Scholars Program, and the Louisiana State University "hierarchical mentoring" program are examples of programs that have resulted in important gains in the persistence of underrepresented minorities in STEM (Matsui et al., 2003; Wilson et al., 2011; Maton et al., 2012). Rather than insisting that every idea be new, we should carefully examine existing programs to see whether there are viable opportunities to apply them to similar challenges at other institutions. For example, UMBC is collaborating with two other majority-serving research universities, Pennsylvania State University and the University of North Carolina at Chapel Hill, to understand how the Meyerhoff Scholars Program can be successfully adapted to and adopted on another campus (DePass and Chubin, 2015). Because programs are often designed to address specific needs, their successful implementation on other campuses requires adapting essential program elements to work in a different context.

\section{Alignment}

As Justice Sotomayor wrote, inclusion is personal. A student's sense of belonging is affected by everything he or she experiences and everyone he or she encounters-his or her instructors, dorm, and fellow students, the campus newspaper, and the language used by faculty and administrators (e.g., Graham et al., 2013; Hurtado and Alvarado, 2015). A campus should gather its many parts to work together to create a climate that openly values inclusion of all persons. Current initiatives on the STEM landscape are utilizing alignment strategies to advance impact. For example, the Association of American Colleges and Universities (AACU) Teaching to Increase Diversity and Equity in STEM (TIDES) Program brings together faculty teams that work collectively to share information and insights about inclusive practices (www.aacu.org/tides). Rather than forbidding overlap between grants as a matter of course, shouldn't we encourage institutions to strive for effective synergies? We call on other organizations-funding agencies, accrediting organizations, and scientific societies-to work with us to achieve alignment of different efforts - on a single campus or on several campuses - to maximize the impact of diversity initiatives.

\section{Institutional Accountability}

The responsibility to build and sustain an inclusive climate that supports access and success of all students resides at the organizational level. While committed faculty, funding, and campus champions are essential in initiating efforts, real and sustained progress will require concerted action within and among institutions. At many colleges and universities, stand-alone interventions such as summer bridge programs or cohort learning communities might be effective for as long as they are funded, but they do not result in the school's lasting capacity for inclusion. What these programs can do, however, is provide "experimental incubators" through which the institution can learn how to integrate inclusive practices across the campus. Institutional accountability includes the intentional skills development of faculty and administrators so they have the opportunity to learn 
how to communicate about and across differences and effectively integrate active learning in their teaching. Institutional capacity includes changing the curriculum and modernizing the expectations of faculty so students can be successful and faculty will be encouraged to participate in activities that promote inclusion of students from all backgrounds. Institutional accountability includes the frank assessment of campus climate for inclusion and the continuous measurement of institutional progress (AACU, 2015). The Howard Hughes Medical Institute's current initiative Inclusive Excellence: Engaging All Students in Science, challenges colleges and universities to significantly improve their capacity for inclusion so all students-especially those who are currently underrepresented-can be successful (www.hhmi.org/programs/undergraduate-science-education -grants).

Our nation has made progress in the last several decades. There is a growing awareness of the importance of diversity. The numbers of underrepresented minorities in STEM have increased. Several strategies have been shown to work, and knowledgeable leaders have emerged who are committed to inclusive excellence in STEM. While these advances deserve celebration, they also bring into focus how far we have yet to go. The need to increase our capacity for inclusion is too urgent for any of us to be content with our present rate of progress.

By insisting that institutions take responsibility for creating inclusive campuses, leveraging successful models through adaptation and adoption, and aligning strategies across the STEM ecosystem, we can double the persistence of students from all backgrounds in STEM by 2025. As our nation resolved to do five decades ago, so now again must we reach for the stars.

\section{REFERENCES}

Association of American Colleges and Universities (2015). Step Up \& Lead for Equity: What Higher Education Can Do to Reverse Our Deepening Divides. www.aacu.org/sites/default/files/StepUpLeadEquity.pdf (accessed 1 July 2016)

Committee on Underrepresented Groups and the Expansion of the Science and Engineering Workforce Pipeline (2011). Expanding Underrepresented Minority Participation: America's Science and Technology Talent at the Crossroads, Washington, D.C.: National Academies Press. www.nap.edu/ catalog/12984/expanding-underrepresented-minority-participation -americas-science-and-technology-talent-at (accessed 1 July 2016).
DePass AL, Chubin DE (eds.) (2015). Understanding Interventions That Broaden Participation in Research Careers, vol. 6, Growing the Community, 58-62. http://understanding-interventions.org/wp-content/uploads/ 2015/06/Understanding-Interventions-2014.pdf (accessed 1 July 2016). See also: www.hhmi.org/news/three-universities-unite-replicate-and -spread-successful-stem-program (accessed 1 July 2016).

Graham MJ, Frederick J, Byars-Winston A, Hunter A-B, Handelsman J (2013). Increasing persistence of college students in STEM. Science 341, 14551456.

Huang G, Taddese N, Walter E, Peng SS (2000). Entry and Persistence of Women and Minorities in College Science and Engineering Education, Washington, D.C.: U.S. Department of Education. National Center for Education Statistics. http://nces.ed.gov/pubs2000/2000601.pdf (accessed 1 July 2016).

Hurtado S, Alvarado AR (2015). Discrimination and Bias, Underrepresentation, and Sense of Belonging on Campus, Research Brief, October 2015 Los Angeles: Higher Education Research Institute at UCLA. www.heri ucla.edu/PDFs/Discriminination-and-Bias-Underrepresentation -and-Sense-of-Belonging-on-Campus.pdf (accessed 1 July 2016).

Jackson SE, Joshi A (2011). Work team diversity. In: APA Handbook of Industrial and Organizational Psychology, vol. 1, ed. S Zedeck, Washington, D.C.: American Psychological Association, chap. 20.

Kets W, Sandroni A (2015). Challenging Conformity: A Case for Diversity. http://wkets.org/wp-content/uploads/2015/11/KetsSandroni_Diversity4 .pdf (accessed 1 July 2016)

Maton KI, Pollard SA, McDougall Weise TV, Hrabowski FA III (2012). The Meyerhoff Scholars Program: a strengths-based, institution-wide approach to increasing diversity in science, technology, engineering and mathematics. Mt Sinai J Med 79, 610-623.

Matsui J, Liu R, Kane CM (2003). Evaluating a science diversity program at UC Berkeley: more questions than answers. Cell Biol Educ 2, 177-121.

National Center for Education Statistics (2013). Digest of Education Statistics: Table 203.50: Enrollment and Percentage Distribution of Enrollment in Public Elementary and Secondary Schools, by Race/Ethnicity and Region: Selected Years, Fall 1995 through Fall 2023. http://nces.ed .gov/programs/digest/d13/tables/dt13_203.50.asp (accessed 1 July 2016)

National Center for Science and Engineering Statistics (2015). Women Minorities, and Persons with Disabilities in Science and Engineering www.nsf.gov/statistics/2015/nsf15311 (accessed 1 July 2016).

Page SE (2007). The Difference: How The Power of Diversity Creates Better Groups, Firms, Schools, and Societies, Princeton, NJ: Princeton University Press.

U.S. Census Bureau, various reports. Data summarized in: https://en.wikipedia .org/wiki/Historical_racial_and_ethnic_demographics_of_the_United States (accessed 1 July 2016)

Wilson ZS, Holmes L, deGravelles K, Sylvain MR, Batiste L, Johnson M, McGuire SY, Pang SS, Warner IM (2011). Hierarchical mentoring: a transformative strategy for improving diversity and retention in undergraduate STEM disciplines. J Sci Educ Technol 21, 148-156. 